\title{
Treatment of brain metastases
}

\author{
Marcel Matzenauer ${ }^{\mathrm{a}}$, David Vrana ${ }^{\mathrm{a}, \mathrm{b}, \mathrm{c}}$, Bohuslav Melichara ${ }^{\mathrm{a}, \mathrm{b}}$
}

\begin{abstract}
Background. Brain metastases are a very common neurological sequela in cancer patients. The ability of current anticancer therapies to prolong overall survival is beleaguered by this development in the case of a number of different cancers. This review provides a general overview of relevant treatment modalities, highlights major decision strategies used in selecting the optimal treatment algorithm and summarizes important steps necessary before initiating therapy. Methods. A PubMed database search was done to identify publications describing the treatment of brain metastases including surgery, radiotherapy and symptomatic care.

Results and Conclusion. Patient performance status and extent of disease play the most important roles in selecting between an aggressive or more conservative approach. As several other options are available, treatment decisions should be made in cooperation with multiple medical specialties and the involvement of multidisciplinary teams. In the future, brain metastases could become less of a treatment obstacle than they are today.
\end{abstract}

Key words: brain, metastases, stereotactic, whole-brain, radiotherapy, radiosurgery, neurosurgery, chemotherapy

Received: July 4, 2016; Accepted with revision: November 10, 2016; Available online: November 23, 2016 https://doi.org/10.5507/bp.2016.058

${ }^{a}$ Department of Oncology, Faculty of Medicine and Dentistry, Palacky University Olomouc, Czech Republic ' Institute of Molecular and Translational Medicine, Faculty of Medicine and Dentistry, Palacky University Olomouc and University Hospital Olomouc, Czech Republic

'Toxicogenomics Unit, National Institute of Public Health, Prague, Czech Republic

Corresponding author: David Vrana, e-mail:davvrana@gmail.com

\section{INTRODUCTION}

The therapeutic strategy in the management of brain metastases depends on a number of factors: type of cancer, systemic tumor burden, available systemic treatment options, number and size of metastases and, location and performance status. Surgical resection, radiotherapy, systemic medical treatment and supportive care are the four principal pillars of therapy in patients presenting with brain metastases.

Two prognostic scoring systems are currently available as an aid to optimize treatment decision. These include the Recursive Partitioning Analysis (RPA), an older method for assessing patient prognosis ${ }^{1}$, and a newer one, the Graded Prognostic Assessment (GPA) which is now more widely used. The RPA classification that was used for several years did not include information about the type of primary tumor. However, Sanghavi et al. (2001) in a retrospective study, confirmed that the RPA class is a significant predictive factor (median survival 16.1 months for class I vs. 10.3 months for class II vs. 8.7 months for class III, $P=0.000007)$. The beneficial effect of stereotactic surgery was also confirmed by significantly longer overall survival compared to overall survival in the original RPA analysis ${ }^{2}$. Owing to marked differences in prognosis for patients with brain metastases due to different tumor types, with advances in new systemic treatment options, the RPA was becoming less accurate over time and the GPA was introduced. Patients in the cited study were analyzed for prognostic factors that were significant for outcome. Significant parameters were then used to define individual sections of the final GPA scoring index. The median overall survival for all patients analyzed was 7.2 months. This index could be used for estimation of survival in individual patients based on specific prognostic factors for each primary. Expected median survival can be calculated from the GPA score. The maximum score index is 4 , and the minimum is 0 . Patients could be stratified into groups with poor prognosis (GPA score 0 to 1.0 ) and favorable prognosis (GPA 1.0 to 3.0). This scoring system indicates that prognostic factors are significantly different from one tumor type to another. It has been demonstrated that all metastatic tumors have the same poor prognosis of approximately 3 months with a GPA index of 0 to 1.0 regardless of histology. Hence, these patients should be treated with a more conservative approach. Performance status has been a common prognostic factor for all tumors. Breast cancer is a diagnosis with the highest expected survival given a GPA score $>1.0$ with an overall median survival time of 13.8 months, in gastrointestinal cancers $36 \%$ of patients had a GPA score of 0 to 1.0 representing a subgroup with the worst expected outcome ${ }^{3}$.

\section{Treatment of brain metastases in patients with poor prognosis}

Treatment of patients with brain metastases and poor prognosis is highly controversial because opting for omission of any therapy other than symptomatic care is a decision that is very difficult to make with regard to the preferences of the patient and his/her family. However, patients frequently benefit more from symptomatic ther- 
apy alone which alleviates symptoms caused by perifocal brain edema at metastatic sites. A more aggressive treatment, e.g. WBRT (whole brain radiotherapy), might even be harmful in patients with poor expected survival.

The most important components of symptomatic treatment are corticosteroids which can relieve the symptoms of brain edema very quickly ${ }^{4}$. Dexamethasone is the corticosteroid of choice owing to minimal mineralocorticoid effect. For symptomatic patients, the starting dose of dexamethasone should range from 4 to $8 \mathrm{mg} /$ day but for patients with more severe symptoms, a dose of $16 \mathrm{mg} /$ day or higher should be considered ${ }^{5}$. However, higher doses are associated with significantly greater toxicity ${ }^{6}$.

As with other corticosteroids, the treatment should remain as short as possible. Fast tapering should also be avoided, and the optimal schedule is $50 \%$ reduction of dexamethasone dose every 4 days until the lowest sufficient dose is reached ${ }^{7}$. Intravenous drug delivery is preferred in patients with poor neurological status. Medication for metastases-related seizures might also be needed. The treatment of choice is antiepileptic drug monotherapy, e.g. levetiracetam ${ }^{8}$.

It has been suggested that in selecting a therapy, it is important to distinguish whether the poor prognosis is determined by intracranial versus extracranial disease. Chernov et al. suggested that stereotactic radiosurgery (SRS) may be appropriate for patients with poor Karnofsky performance status $(<50 \%)$ caused by the presence of intracranial metastases but not for patients in poor condition because of uncontrolled extracerebral disease. The median survival was 6 months in the group with poor performance status due to cerebral metastases and no extracerebral disease, and 1 month in patients with uncontrolled extracranial metastases ${ }^{9}$. Whole brain radiation therapy is considered a standard treatment modality for patients with poor prognosis. However, there is a dearth of evidence to support this approach in this patient subgroup (GPA score of 0-1). The benefit of addition of WBRT to OSC (optimal supportive care) was evaluated in the QUARTZ study whose interim data was published in 2012. The primary outcome was QALYs (quality-adjusted life years) and it analyzed patients with brain metastases from NSCLC (non-small cell lung cancer). In total, 151 patients were randomized, 75 to OSC+WBRT and 76 to OSC only. Median age was 67 years. The steroid usage was similar in both groups. WBRT was given in 5 fractions to a total dose of $20 \mathrm{~Gy}$. In the WBRT+OSC group, the median survival was 49 days (95\% confidence interval 39 - 61), while in the OSC only group the median survival was 51 days (95\% confidence interval 27-57) with an HR of 1.11 (95\% confidence interval $0.80-1.53$ ) in favor of WBRT. The observed QALYs were 31 days for OSC in combination with WBRT and 30 days for OSC, with an absolute difference of 1 day (95\% confidence interval -12.0 to +13.2 days). These data therefore support a more conservative approach in patients with poor prognosis but also suggest that the WBRT does not have a detrimental effect on patient quality of life ${ }^{10}$. Another study compared radiotherapy and best supportive care in this setting. Nieder et al. (2013) analyzed both patients with NSCLC and other malignancies. The median overall survival of 113 patients was 2 months. WBRT was delivered in a total dose of 20 or $30 \mathrm{~Gy}$, respectively. This study also confirmed that there was not a significant difference between the two treatment groups, with the exception of patients with small cell lung cancer (SCLC). This group had significant benefit from a WBRT of $30 \mathrm{~Gy}$. The difference in median survival was 4.7 months ( 0.6 versus 5.3 months; $P=0.001$ ). There was no obvious difference in risk factors between the two groups but there were only 6 patients in the SCLC group ${ }^{11}$.

\section{Treatment of brain metastases in patients with favorable prognosis}

In general, patients with brain metastases from gastrointestinal tumors and a GPA score above 1.0 have an overall survival of at least 4.4 months. Other tumor groups have a better expected outcome ${ }^{2}$. With respect to highly individualized therapy approaches, the choice of aggressive treatment modality should be made mainly according to expected survival which is predominantly determined by extracranial extent of disease. For this reason the treatment of brain metastases should neither start nor proceed until all staging diagnostic procedures have been performed and all necessary information obtained. As mentioned above, the treatment modalities include whole brain radiation therapy, surgery, stereotactic radiosurgery and systemic therapy ${ }^{12}$. In selecting an appropriate treatment strategy, the extent of CNS disease needs to be assessed as the number and size of brain metastases affect the treatment decision. Contrast-enhanced MRI is more appropriate in this setting because it provides higher sensitivity of detection ${ }^{13}$. Based on the total number of brain metastases, patients can be divided into three groups that are treated with different modality approaches, including patients with single brain metastasis, with two to three lesions and patients with more than three brain metastase ${ }^{14}$. The two most common sites of metastases are the hemispheres and cerebellum, i.e. sites accessible to surgical treatment. Hence the resectability of the tumor is usually limited by adjacent functionally important regions and surgical technique, although good performance status and controlled extracranial disease remain a precondition for this approach ${ }^{15,16}$. Surgery allows prompt removal of tumor causing perifocal edema and especially for tumors larger than $3 \mathrm{~cm}$, particularly in the posterior fossa ${ }^{16}$ and also provides information on tumor histology. The goal of surgery is to achieve gross total resection (GTR), therefore en bloc removal is preferred whenever possible and this method does not necessarily imply higher rate of complications ${ }^{17}$. Patchell et al. randomly assigned 48 patients with solitary brain metastasis to surgical resection followed by whole-brain radiotherapy ( $36 \mathrm{~Gy}, 25$ patients) or WBRT only (36 Gy, 23 patients). The median survival of patients in the surgical group was significantly prolonged compared to radiotherapy alone ( 40 vs 15 weeks; $P<0.01$ ) (ref. ${ }^{18}$ ). Vecht et al. randomly assigned 63 patients to surgery and WBRT (40 Gy, 32 patients) versus WBRT only (40 Gy, 31 patients) and observed a significant survival benefit (median 10 vs 6 months $P<0.04$ ) (ref. ${ }^{19}$ ). However, 
these studies were published in the 1990s. The benefit of surgery compared to WBRT in single brain metastasis may be even greater today with the utilization of modern neurosurgical techniques. Surgery is of advantage in lesions such as metastases with herniation, large posterior fossa metastases and those with brain stem compression ${ }^{20}$. Further, in up to $10 \%$ of patients with solitary brain metastasis it has been shown that the brain tumor may represent other primary than originally suspected tumors. SRS/SRT is defined by highly conformed dose delivery, steep dose gradient at tumor margin and by non-homogeneous dose distribution inside the irradiated volume allowing accurate treatment and large dose per fraction. SRS/SRT should be used in patients with single brain metastasis of $<3$ $\mathrm{cm}$ and two to four metastases all of $<2.5 \mathrm{~cm}$, the upper limit of lesion diameter that can be safely treated with one fraction is considered to be of 3 to $3.5 \mathrm{~cm}^{21}$. The dose can be delivered in one fraction (stereotactic radiosurgery) or in a fractionated regimen (stereotactic radiotherapy). The principal advantage in comparison to resection is the ability to treat multiple and surgically inaccessible lesions, for instance in the brainstem ${ }^{22,23}$. The cost-effectiveness of SRT vs. surgery in patients with single brain metastasis was assessed by Mehta et al. with the conclusion that surgical resection results in a 1.8-fold increase in cost, but minor difference in outcome ${ }^{24}$. The effectiveness of SRS versus WBRT has been evaluated in multiple studies (Table 1,2). In the RTOG 9508 study published in 2004, a total of 333 patients with single brain metastasis were assigned to treatment with WBRT alone or WBRT with SRS. There was a significant survival improvement in the WBRT plus SRS group (6.5 vs. 4.9 months, $P=0.0393$ ) (Table 1). Patients treated with stereotactic radiotherapy had higher probability of stable or better performance status ( $43 \%$ vs. $27 \%, P=0.03$ ). SRS boost to WBRT was shown to significantly prolong overall survival ${ }^{25}$. A secondary analysis of RTOG 9508 published in 2014 further stratified patients according to the GPA scoring system demonstrating that patients with high GPA (3.5-4) had a survival advantage regardless whether they had 1, 2, or 3 brain metastases, but also indicating lack of survival benefit for the patients not selected by the GPA score ${ }^{26}$.
The benefit of adding WBRT after radiosurgery or neurosurgery was investigated in the EORTC 22952-26001 study published in 2011. In this study, 359 patients of whom 199 were treated with radiosurgery and 160 with surgery, were randomized to adjuvant WBRT or observation. The study showed no difference in overall survival ( 10.9 v 10.7 months, $P=0.89$ ). Intracranial progression resulted in death in 78 (44\%) of 179 patients in the observation arm and in 50 (28\%) of 180 patients in the WBRT arm indicating increased recurrence rates if WBRT was omitted $^{27}$. This study also suggested that overall survival is determined mainly by extracranial disease. Soffietti et. al showed a statistically significant detrimental effect of adding WBRT after SRS or surgery on HRQOL (ref. ${ }^{28}$ ). The efficacy and non-inferiority of stereotactic radiosurgery was also confirmed in patients with 5 to 10 brain metastases in comparison to 2 to 4 metastases (HR 0.97, 95\% CI $0.81-1.18, P=0.78$ ) $\left(\right.$ ref. $\left.^{29}\right)$. Therefore the use of SRS in patients with more than 5 brain metastases and low overall volume should be more utilized and further investigated.

\section{Treatment of recurrent brain metastases}

Treatment of recurrent brain metastases with stereotactic radiosurgery/radiotherapy or salvage surgery is a real challenge. The efficacy of surgery and radiotherapy has been evaluated in several studies. Arbit et al. analyzed 109 patients with recurrent brain metastases of NSCLC. There was recurrence at the original site in $62 \%$ of patients, with recurrence at a different site in the remaining 38\%. Thirty-two patients who underwent surgery after relapse had significantly longer survival (median 15 months) than 77 patients in whom the surgical intervention was omitted (median 10 months, $P<0.001)\left(\right.$ ref. ${ }^{30}$ ). Another study by Vecil et al. showed that surgery was beneficial in patients who relapsed after first line stereotactic radiosurgery. In 61 patients with one to three brain metastases, the median overall survival from the date of salvage surgery was 11.1 months (95\% CI 6.8-15.4 months). Major neurological complications occurred in $2 \%$ of cases, i.e. one patient. The authors recommended using salvage surgery in selected patients with controlled

Table 1. Overview of studies comparing SRS plus WBRT versus WBRT alone.

\begin{tabular}{|c|c|c|c|c|c|c|}
\hline $\begin{array}{l}\text { No. of } \\
\text { patients }\end{array}$ & Primary endpoint & $\begin{array}{l}\text { SRS+WBRT median } \\
\text { OS }\end{array}$ & $\begin{array}{l}\text { WBRT alone median } \\
\text { OS }\end{array}$ & $P$ & Note & Ref. \\
\hline 333 & Overall survival & 6.5 months & 4.9 months & 0.0390 & $\begin{array}{l}\text { Significant only in patients with } \\
\text { single brain metastastasis }\end{array}$ & 25 \\
\hline 60 & Overall survival & 15 months & 5 months & 0.0020 & $\begin{array}{l}\text { Significant only in patients with } \\
\text { single brain metastastasis }\end{array}$ & 48 \\
\hline 27 & Local Control & $\begin{array}{l}11 \text { months } \\
(95 \% \mathrm{CI}, 3.8-18.2)\end{array}$ & $\begin{array}{l}7 \text { months } \\
(95 \% \text { CI, 3.6-10.4) }\end{array}$ & 0.2260 & $\begin{array}{l}\text { Number of metastases had no } \\
\text { impact on survival }\end{array}$ & 49 \\
\hline 88 & $\begin{array}{l}\text { Overall survival, } \\
\text { intracerebral and } \\
\text { local control }\end{array}$ & 16 months & 2 months & $<0.001$ & Retrospective analysis & 50 \\
\hline 275 & Overall survival & $\begin{array}{l}12 \text { months } \\
(95 \% \text { CI, 8.74-15.98) }\end{array}$ & $\begin{array}{l}4.3 \text { months }(95 \% \mathrm{CI} \\
3.30-5.38)\end{array}$ & $<0.001$ & Retrospective analysis & 51 \\
\hline 60 & Overall survival & 13 months & 9.5 months & $<0.0001$ & Retrospective analysis & 52 \\
\hline
\end{tabular}


Table 2. Overview of studies comparing SRS plus WBRT versus SRS alone.

\begin{tabular}{|c|c|c|c|c|c|c|}
\hline $\begin{array}{l}\text { No. of } \\
\text { patients }\end{array}$ & Primary endpoint & $\begin{array}{l}\text { SRS+WBRT } \\
\text { median OS }\end{array}$ & $\begin{array}{l}\text { SRS alone median } \\
\text { OS }\end{array}$ & $P$ & Note & Ref. \\
\hline 132 & Overall survival & 7.5 months & 8 months & 0.42 & WBRT was added upfront & 53 \\
\hline 58 & $\begin{array}{l}\text { Neurocognitive } \\
\text { function at } 4 \text { months }\end{array}$ & 5.7 months & 15.2 months & 0.0030 & $\begin{array}{l}\text { Surgical salvage rate of } 33 \% \text { of } \\
\text { patients in the SRS alone group }\end{array}$ & 54 \\
\hline 359 & $\begin{array}{l}\text { Time to PS deterioration } \\
\text { to more than } 2\end{array}$ & $\begin{array}{l}10.7 \text { months } \\
\text { (95\% CI, } 9.0-14.4 \\
\text { months) }\end{array}$ & $\begin{array}{l}10.9 \text { months } \\
(95 \% \text { CI, } 9.5-14.2 \\
\text { months) }\end{array}$ & 0.89 & & 21 \\
\hline 289 & $\begin{array}{l}\text { Cost-effectiveness } \\
\text { of treatment }\end{array}$ & $\begin{array}{l}7.4 \text { months }(95 \% \\
\text { CI } 5.6-10.3)\end{array}$ & $\begin{array}{l}9.8 \text { months }(95 \% \\
\text { CI } 7.2-11.8)\end{array}$ & 0.2 & Retrospective analysis & 55 \\
\hline 88 & $\begin{array}{l}\text { Overall survival (OS), } \\
\text { intracerebral control and } \\
\text { local control }\end{array}$ & 16 months & 12 months & 0.7030 & Retrospective analysis & 50 \\
\hline 65 & $\begin{array}{l}\text { Developing of white mat- } \\
\text { ter changes }\end{array}$ & 29.7 months & 40.8 months & 0.13 & Retrospective analysis & 56 \\
\hline 213 & $\begin{array}{l}\text { Cognitive } \\
\text { deterioration }\end{array}$ & 7.4 months & 10.4 months & 0.92 & & 57 \\
\hline 135 & Overall survival & 6.4 months & 10.5 months & 0.07 & Retrospective analysis & 58 \\
\hline 236 & Overall survival & 15.4 months & 8.3 months & 0.08 & $\begin{array}{l}\text { Retrospective analysis, patients } \\
\text { without extra cranial disease }\end{array}$ & 59 \\
\hline 569 & Overall survival & 8.6 months & 8.2 months & 0.93 & $\begin{array}{l}\text { Retrospective analysis, WBRT } \\
\text { was added upfront }\end{array}$ & 60 \\
\hline
\end{tabular}

systemic disease and good overall performance status, preferably RPA I (ref. ${ }^{31}$ ). The re-irradiation of brain metastases with SRS after prior SRS was evaluated by Kim et al. (2013). In total, 32 patients were analyzed and the median survival of patients after the first course of SRS/ SRT was 14.6 months (5.3-72.2 months) and 7.9 months (0.7-61.1 months) from re-irradiation with SRS/SRT. The majority of patients ( $71 \%$ ) died without active neurologic symptoms ${ }^{32}$. This analysis therefore supports the adoption of SRS/SRT as a treatment modality of choice in this setting.

\section{Neurocognitive sparing technique}

Neurocognitive decline as an adverse event of WBRT could be avoided if one of several new approaches in sparing cognitive centers are used. With intensity modulated radiotherapy (IMRT) the hippocampus can be spared unnecessary irradiation. Use of this technique called hippocampal avoidance whole brain radiotherapy allows further reduction in the risk of local recurrence but could increase the risk of cognitive decline and recurrence in untreated volume. Further, this radiotherapy technique is time-consuming and technically demanding ${ }^{33}$. The beneficial effect of hippocampal sparing was evaluated in RTOG 0933 phase II trial which reported significantly lower decline of cognitive functions ${ }^{34}$.

\section{Systemic therapy}

Historically, the use of systemic therapy in patients with brain metastases was limited due to the blood brain barrier that limited the efficacy of cytotoxic agents. However, the blood-brain barrier is disrupted in brain metastases resulting in increased exposure to systemic drugs. Additional increase in permeability of the blood- brain barrier can be induced by radiotherapy. The tumor chemo-sensitivity appears to be as important as the role of blood brain barrier permeability ${ }^{35,36}$. In order to achieve best tumor control, treatment should be aimed both at brain metastases and systemic disease. Retrospective analysis of the efficacy of primary WBRT with systemic treatment after radiotherapy was reported by Nieder et al. In this analysis, 189 patients from brain metastases database were analyzed. Timing and type of systemic therapy were chosen according to clinician choice. All patients were assigned DS-GPA and RPA scores. The three most common diagnoses where patients received systemic therapy after completion of WBRT were NSCLC, SCLC and breast cancer, with systemic treatment used in $42 \%$, $50 \%$ and $63 \%$ respectively. $85 \%$ of patients had extracranial metastases and $53 \%$ had more than 3 metastases. The overall survival was significantly longer in patients treated with systemic therapy with a median of $6.4 \mathrm{vs} .2 .1$ months $(P=0.0001)$. The efficacy of systemic therapy in brain metastases may be more pronounced after WBRT but the benefit is mostly attributed to the control of systemic disease ${ }^{37}$. Systemic therapy in patients with brain metastases differs according to the primary, and there are numerous examples of systemic therapy markedly affecting the outcome.

Metastatic breast cancer is a chemosensitive tumor, including cases with brain metastases. The benefit of systemic therapy (lapatinib plus capecitabine) in patients with HER-2-positive breast cancer and brain metastases was confirmed in the LANDSCAPE single-arm phase II trial. Patients with HER2 positive breast cancer plus brain metastases who had no pretreatment with WBRT, lapatinib or capecitabine were assessed for CNS response, defined as a $50 \%$ or greater reduction in volume of CNS 
lesions without increased steroid dosing, worsening neurological symptoms or progressive extracranial disease. In total, 29 of 44 assessable patients achieved objective CNS response on systemic treatment with lapatinib and capecitabine $(65.9 \%, 95 \%$ CI 50.1-79.5). This study confirmed the effect of this combination on brain metastases, warranting further investigation ${ }^{38}$. The effect of systemic treatment has also been presented in a number of case reports. For example, in a case report of a 50-year old patient with breast cancer and brain metastases with good DS-GPA score, repeated partial response of brain metastases after systemic treatment was observed. The first remission was achieved after T-DM1 (trastuzumab emtansine) and the second after trastuzumab, lapatinib plus capecitabine ${ }^{39}$.

SCLC is another example of a chemosensitive tumor with frequent brain metastases. However, the benefit of adding systemic therapy to WBRT in patients with SCLC has not been established as shown in EORTC phase III trial that randomized 120 patients to teniposide alone and teniposide plus WBRT arms. Time to progression was significantly longer with the combined approach but no overall survival benefit was found with a median survival of 3.2 and 3.5 months $(P=0.087)$, respectively ${ }^{40}$. Brain metastases are also common in NSCLC. Gerber et al. assessed the benefit of systemic therapy in patients with NSCLC. A total of 110 patients with EGFR mutated lung adenocarcinoma were assigned to treatment with erlotinib (63 patients), WBRT (32 patients) and SRS (15 patients). No significant difference in median OS was found between erlotinib and WBRT groups (26 vs 35 months; $P=0.62)$. The longest median OS was in the SRS group (64 months; $P=0.004$ ) (ref. ${ }^{41}$ ).

Systemic therapy is also important for patients with metastatic germ cell tumors with involvement of the CNS (ref. ${ }^{42}$ ).

Moreover, new immunotherapies could increase the number of patients with brain metastases treated with systemic therapy, specifically in melanoma, RCC and NSCLC (ref. ${ }^{43,44}$ ). Further increase in the efficacy of chemotherapy may be achieved by using new data on transportation of chemotherapeutic agents over the cell membrane or biotransforming enzymes that metabolize the chemotherapy ${ }^{45-47}$.

\section{CONCLUSION}

Management of brain metastases is continuously and rapidly evolving. The preference for each treatment modality is influenced by emerging approaches, such as using new techniques in neurosurgery which allow gross tumor resection more easily and safely, using stereotactic radiotherapy alone or in combination with WBRT or neurocognitive function sparing techniques, e.g. avoiding hippocampus irradiation during the treatment of brain metastases and new systemic treatment options, including immunotherapy. Further research, preferably prospective trials, is clearly needed to guide clinicians about appropriate treatment strategies.
Acknowledgement: IGA_LF_2016_014.

Author contributions: $\mathrm{MM}, \overline{\mathrm{DV}}$ : study design; BM, MM, DV: manuscript writing.

Conflict of interest statement: The authors state that there are no conflicts of interest regarding the publication of this article.

\section{REFERENCES}

1. Gaspar L, Scott C, Rotman M, Asbell S, Phillips T, Wasserman T, McKenna WG, Byhardt R. Recursive partitioning analysis (RPA) of prognostic factors in three Radiation Therapy Oncology Group (RTOG) brain metastases trials. Int J Radiat Oncol Biol Phys 1997;37(4):745-51.

2. Sanghavi SN, Miranpuri SS, Chappell R, Buatti JM, Sneed PK, Suh JH, Regine WF, Weltman E, King VJ, Goetsch SJ, Breneman JC, Sperduto PW, Scott C, Mabanta S, Mehta MP. Radiosurgery for patients with brain metastases: a multi-institutional analysis, stratified by the RTOG recursive partitioning analysis method. Int J Radiat Oncol Biol Phys 2001;51(2):426-34.

3. Sperduto PW, Chao ST, Sneed PK, Luo X, Suh J, Roberge D, Bhatt A, Jensen AW, Brown PD, Shih H, Kirkpatrick J, Schwer A, Gaspar LE, Fiveash JB, Chiang V, Knisely J, Sperduto CM, Mehta M. Diagnosisspecific prognostic factors, indexes, and treatment outcomes for patients with newly diagnosed brain metastases: a multi-institutional analysis of 4,259 patients. Int J Radiat Oncol Biol Phys 2010;77(3):655-61.

4. Alberti E, Hartmann A, Schütz HJ, Schreckenberger F. The effect of large doses of dexamethasone on the cerebrospinal fluid pressure in patients with supratentorial tumors. J Neurol 1978;217(3):173-81.

5. Ryken TC(1), McDermott $M$, Robinson PD, Ammirati M, Andrews DW, Asher AL, Burri SH, Cobbs CS, Gaspar LE, Kondziolka D, Linskey ME, Loeffler JS, Mehta MP, Mikkelsen T, Olson JJ, Paleologos NA, Patchell RA, Kalkanis SN. The role of steroids in the management of brain metastases: a systematic review and evidence-based clinical practice guideline. Department of Neurosurgery, lowa Spine and Brain Institute, lowa City, USA J Neurooncol 2010;96(1):103-14.

6. Vecht CJ, Hovestadt A, Verbiest HB, van Vliet JJ, van Putten WL (1994) Dose-effect relationship of dexamethasone on Karnofsky performance in metastatic brain tumors: a randomized study of doses of 4, 8, and $16 \mathrm{mg}$ per day. Neurology 44(4):675-80.

7. Koehler PJ. Use of corticosteroids in neuro-oncology. Anticancer Drugs 1995;6(1):19-33.

8. Rossetti AO, Stupp R. Epilepsy in brain tumor patients. Curr Opin Neurol 2010;23(6):603-9.

9. Chernov MF, Nakaya K, Izawa M, Hayashi M, Usuba Y, Kato K, Muragaki $Y$, Iseki $\mathrm{H}$, Hori T, Takakura K. Outcome after radiosurgery for brain metastases in patients with low Karnofsky performance scale (KPS) scores. Int J Radiat Oncol Biol Phys 2007;67(5):1492-8.

10. Langley RE, Stephens RJ, Nankivell M, Pugh C, Moore B, Navani N, Wilson P, Faivre-Finn C, Barton R, Parmar MK, Mulvenna PM; QUARTZ Investigators. Interim data from the Medical Research Council QUARTZTrial: does whole brain radiotherapy affect the survival and quality of life of patients with brain metastases from non-small cell lung cancer? Clin Oncol (R Coll Radiol) 2013;25(3):e23-30.

11. Nieder C, Norum J, Dalhaug A, Aandahl G, Pawinski A. Radiotherapy versus best supportive care in patients with brain metastases and adverse prognostic factors. Clin Exp Metastasis 2013;30(6):723-9.

12. Posner JB. Management of brain metastases. Rev Neurol (Paris) 1992;148(6-7):477-87.

13. Davis PC, Hudgins PA, Peterman SB, Hoffman JC Jr. Diagnosis of cerebral metastases: double-dose delayed $C T$ vs contrast-enhanced MR imaging. AJNR Am J Neuroradiol 1991;12(2):293-300.

14. Modha A, Shepard SR, Gutin PH. Surgery of brain metastases--is there still a place for it? J Neurooncol 2005;75(1):21-9.

15. Mut M. Surgical treatment of brain metastasis: a review. Clin Neurol Neurosurg 2012;114(1):1-8.

16. Vogelbaum MA, Suh JH. Resectable brain metastases. J Clin Oncol 2006;24(8):1289-94.

17. Patel AJ, Suki D, Hatiboglu MA, Rao VY, Fox BD, Sawaya R. Impact of surgical methodology on the complication rate and functional 
outcome of patients with a single brain metastasis. J Neurosurg 2015;122(5):1132-43.

18. Patchell RA, Tibbs PA, Walsh JW, Dempsey RJ, Maruyama Y, Kryscio RJ,Markesbery WR, Macdonald JS, Young B. A randomized trial of surgery in the treatment of single metastases to the brain. $N$ Engl $J$ Med 1990;322(8):494-500.

19. Vecht CJ, Haaxma-Reiche H, Noordijk EM, Padberg GW, Voormolen $\mathrm{JH}$, Hoekstra FH,Tans JT, Lambooij N, Metsaars JA, Wattendorff AR, et al. Treatment of single brain metastasis: radiotherapy alone or combined with neurosurgery? Ann Neurol 1993;33(6):583-90.

20. Levitt MR, Levitt R, Silbergeld DL. Controversies in the management of brain metastases. Surgical Neurology International 2013:4(S4):S231-S235.

21. Kocher M, Wittig A, Piroth MD, Treuer $H$, Seegenschmiedt $H$, Ruge $M$, Grosu AL, Guckenberger M. Stereotactic radiosurgery for treatment of brain metastases. A report of the DEGRO Working Group on Stereotactic Radiotherapy. Strahlenther Onkol 2014;190(6):521-32.

22. Hussain A, Brown PD, Stafford SL, Pollock BE. Stereotactic radiosurgery for brain stem metastases: Survival, tumor control, and patient outcomes. Int J Radiat Oncol Biol Phys 2007;67(2):521-4.

23. Halasz LM, Rockhill JK. Stereotactic radiosurgery and stereotactic radiotherapy for brain metastases. Surgical Neurology International 2013:4(S4):S185-S191.

24. Mehta M, Noyes W, Craig B, Lamond J, Auchter R, French M, Johnson M, Levin A, Badie B, Robbins I, Kinsella T. A cost-effectiveness and cost-utility analysis of radiosurgery vs. resection for single-brain metastases. Int J Radiat Oncol Biol Phys 1997;39(2):445-54.

25. Andrews DW, Scott CB, Sperduto PW, Flanders AE, Gaspar LE, Schell MC, Werner-Wasik M, Demas W, Ryu J, Bahary JP, Souhami L, Rotman M, Mehta MP, Curran, WJ Jr. Whole brain radiation therapy with or without stereotactic radiosurgery boost for patients with one to three brain metastases: phase III results of the RTOG 9508 randomised trial. Lancet 2004;363(9422):1665-72.

26. Sperduto PW, Shanley R, Luo X, Andrews D, Werner-Wasik M, Valicenti R, Bahary JP, Souhami L, Won M, Mehta M. Secondary analysis of RTOG 9508, a phase 3 randomized trial of whole-brain radiation therapy versus WBRT plus stereotactic radiosurgery in patients with 1-3 brain metastases; poststratified by the graded prognostic assessment (GPA). Int J Radiat Oncol Biol Phys 2014;90(3):526-31.

27. Kocher $M$, Soffietti R, Abacioglu U, et al. Adjuvant Whole-Brain Radiotherapy Versus Observation After Radiosurgery or Surgical Resection of One to Three Cerebral Metastases: Results of the EORTC 22952-26001 Study. Journal of Clinical Oncology 2011;29(2):134-41.

28. Soffietti R, Kocher M, Abacioglu UM, Villa S, Fauchon F, Baumert BG, Fariselli L, Tzuk-Shina T, Kortmann RD, Carrie C, Ben Hassel M, Kouri M, Valeinis E, vanden Berge D, Mueller RP, Tridello G, Collette L, Bottomley A. A European Organisation for Research and Treatment of Cancer phase III trial of adjuvant whole-brain radiotherapy versus observation in patients with one to three brain metastases from solid tumors after surgical resection or radiosurgery: quality-of-life results. J Clin Oncol 2013;31(1):65-72.

29. Yamamoto M, Serizawa T, Shuto T, Akabane A, Higuchi Y, Kawagish J, Yamanaka K, Sato Y, Jokura H, Yomo S, Nagano O, Kenai H, Morik A, Suzuki S, Kida Y, Iwai Y, Hayashi M, Onishi H, Gondo M, Sato M, Akimitsu T, Kubo K, Kikuchi Y, Shibasaki T, Goto T, Takanashi M, Mori Y, Takakura K, Saeki N, Kunieda E, Aoyama H, Momoshima S, Tsuchiya K. Stereotactic radiosurgery for patients with multiple brain metastases (JLGK0901): a multi-institutional prospective observational study. Lancet Oncol 2014;15(4):387-95.

30. Arbit E, Wroński M, Burt M, Galicich JH. The treatment of patients with recurrent brain metastases. A retrospective analysis of $109 \mathrm{pa}-$ tients with nonsmall cell lung cancer. Cancer 1995;76(5):765-73.

31. Vecil GG, Suki D, Maldaun MV, Lang FF, Sawaya R. Resection of brain metastases previously treated with stereotactic radiosurgery. J Neurosurg 2005;102(2):209-15.

32. Kim DH, Schultheiss TE, Radany EH, Badie B, Pezner RD. Clinical outcomes of patients treated with a second course of stereotactic radiosurgery for locally or regionally recurrent brain metastases after prior stereotactic radiosurgery. J Neurooncol 2013;115(1):37-43.

33. Vrána D, Študentová H, Matzenauer M, Vlachová Z, Cwiertka K, Gremlica D, Kalita O. Treatment of brain metastases of renal cell cancer with combined hypofractionated stereotactic radiotherapy and whole brain radiotherapy with hippocampal sparing. Oncol Lett 2016;11(6):3777-81.
34. Gondi V, Pugh SL, Tome WA, Caine C, Corn B, Kanner A, Rowley H, Kundapur V, DeNittis A, Greenspoon JN, Konski AA, Bauman GS, Shah S, Shi W, Wendland M, Kachnic L, Mehta MP. Preservation of memory with conformal avoidance of the hippocampal neural stem-cell compartment during whole-brain radiotherapy for brain metastases (RTOG 0933): a phase II multi-institutional trial. J Clin Oncol 2014;32(34):3810-6.

35. Postmus PE, Smit EF. Chemotherapy for brain metastases of lung cancer: a review. Ann Oncol 1999;10(7):753-9.

36. Melichar B, Urminská H, Kohlová T, Nová M, Česák T. Brain metastases of epithelial ovarian carcinoma responding to cisplatin and gemcitabine combination chemotherapy: a case report and review of the literature. Gyn Oncol 2004;94:267-76.

37. Nieder C, Marienhagen K, Dalhaug A, Aandahl G, Haukland E, Pawinski A. Impact of systemic treatment on survival after whole brain radiotherapy in patients with brain metastases. Med Oncol 2014:31(4):927.

38. Bachelot T, Romieu G, Campone M, Diéras V, Cropet $C$, Dalenc $F$ Jimenez M, Le Rhun E, Pierga JY, Gonçalves A, Leheurteur M, Domont J, Gutierrez M, Curé H, Ferrero JM, Labbe-Devilliers C. Lapatinib plus capecitabine in patients with previously untreated brain metastases from HER2-positive metastatic breast cancer (LANDSCAPE): a singlegroup phase 2 study. Lancet Oncol 2013;14(1):64-71.

39. Bergen ES, Berghoff AS, Rudas M, Preusser M, Bartsch R. Breast cancer brain metastases responding to lapatinib plus capecitabine as second-line primary systemic therapy. Anticancer Drugs 2015;26(5):579-81.

40. Postmus PE, Haaxma-Reiche H, Smit EF, Groen HJ, Karnicka $H$, Lewinski T, van Meerbeeck J, Clerico M, Gregor A, Curran D, Sahmoud T, Kirkpatrick A, Giaccone G. Treatment of brain metastases of smallcell lung cancer: comparing teniposide and teniposide with wholebrain radiotherapy--a phase III study of the European Organization for the Research and Treatment of Cancer Lung Cancer Cooperative Group. J Clin Oncol 2000;18(19):3400-8.

41. Gerber NK, Yamada Y, Rimner A, Shi W, Riely GJ, Beal K, Yu HA, Chan TA, Zhang Z, Wu AJ. Erlotinib versus radiation therapy for brain metastases in patients with EGFR-mutant lung adenocarcinoma. Int J Radiat Oncol Biol Phys 2014;89(2):322-9.

42. Bokemeyer C, Nowak P, Haupt A, Metzner B, Köhne H, Hartmann JT, Kanz L, Schmoll HJ. Treatment of brain metastases in patients with testicular cancer. J Clin Oncol 1997;15(4):1449-54.

43. Tazi K, Hathaway A, Chiuzan C, Shirai K. Survival of melanoma patients with brain metastases treated with ipilimumab and stereotactic radiosurgery. Cancer Med 2015;4(1):1-6.

44. Brastianos HC, Cahill DP, Brastianos PK. Systemic therapy of brain metastases. Curr Neurol Neurosci Rep 2015;15(2):518.

45. Hlaváč V, Brynychová V, Václavíková R, Ehrlichová M, Vrána D, Pecha V, Trnková M, Kodet R, Mrhalová M, Kubáčková K, Gatěk J, Vážan $P$, Souček P. The role of cytochromes p450 and aldo-keto reductases in prognosis of breast carcinoma patients. Medicine (Baltimore) 2014;93(28):e255.

46. Kunická T, Václavíková R, Hlaváč V, Vrána D, Pecha V, Rauš K, Trnková M, Kubáčková K, Ambruš M, Vodičková L, Vodička P, Souček P. Noncoding polymorphisms in nucleotide binding domain 1 in ABCC 1 gene associate with transcript level and survival of patients with breast cancer. PLoS One 2014;9(7):e101740.

47. Vrana D, Novotny J, Holcatova I, Hlavata I, Soucek P. CYP1B1 gene polymorphism modifies pancreatic cancer risk but not survival. Neoplasma 2010;57(1):15-9.

48. El Gantery MM, Abd El Baky HM, El Hossieny HA, Mahmoud M, Youssef $O$. Management of brain metastases with stereotactic radiosurgery alone versus whole brain irradiation alone versus both. Radiat Oncol 2014;9:116.

49. Kondziolka D, Patel A, Lunsford LD, Kassam A, Flickinger JC. Stereotactic radiosurgery plus whole brain radiotherapy versus radiotherapy alone for patients with multiple brain metastases. Int $J$ Radiat Oncol Biol Phys 1999;45(2):427-34.

50. Fokas E, Henzel M, Hamm K, Surber G, Kleinert G, Engenhart-Cabillic R. Radiotherapy for brain metastases from renal cell cancer: should whole-brain radiotherapy be added to stereotactic radiosurgery?: analysis of 88 patients. Strahlenther Onkol 2010;186(4):210-7.

51. Elaimy AL, Mackay AR, Lamoreaux WT, Fairbanks RK, Demakas JJ, Cooke BS, Peressini BJ, Holbrook JT, Lee CM. Multimodality treat- 
ment of brain metastases: an institutional survival analysis of 275 patients. World J Surg Oncol 2011;9:69.

52. Jiang XB, Yang QY, Sai K, Zhang XH, Chen ZP, Mou YG. Brain metastases from colorectal carcinoma: a description of 60 cases in a single Chinese cancer center. Tumour Biol 2011;32(6):1249-56.

53. Aoyama $H$, Shirato $H$, Tago $M$, Nakagawa K, Toyoda T, Hatano K, Kenjyo M, Oya N, Hirota S, Shioura H, Kunieda E, Inomata T, Hayakawa K, Katoh N, Kobashi G. Stereotactic radiosurgery plus whole-brain radiation therapy vs stereotactic radiosurgery alone for treatment of brain metastases: a randomized controlled trial. JAMA 2006;295(21):2483-91.

54. Chang EL, Wefel JS, Hess KR, Allen PK, Lang FF, Kornguth DG, Arbuckle RB, Swint JM, Shiu AS, Maor MH, Meyers CA. Neurocognition in patients with brain metastases treated with radiosurgery or radiosurgery plus whole-brain irradiation: a randomised controlled trial. Lancet Oncol 2009;10(11):1037-44.

55. Hall MD, McGee JL, McGee MC, Hall KA, Neils DM, Klopfenstein JD, Elwood PW. Cost-effectiveness of stereotactic radiosurgery with and without whole-brain radiotherapy for the treatment of newly diagnosed brain metastases. J Neurosurg 2014;121 Suppl:84-90.

56. Stokes TB, Niranjan A, Kano H, Choi PA, Kondziolka D, Dade Lunsford $\mathrm{L}$, Monaco EA 3rd. White matter changes in breast cancer brain metastases patients who undergo radiosurgery alone compared to whole brain radiation therapy plus radiosurgery. J Neurooncol 2015;121(3):583-90.

57. Brown PD, Jaeckle K, Ballman KV, Farace E, Cerhan JH, Anderson SK, Carrero XW, Barker FG 2nd, Deming R, Burri SH, Ménard C, Chung C, Stieber VW, Pollock BE, Galanis E, Buckner JC, Asher AL. Effect of Radiosurgery Alone vs Radiosurgery With Whole Brain Radiation Therapy on Cognitive Function in Patients With 1 to 3 Brain Metastases: A Randomized Clinical Trial. JAMA 2016;316(4):401-9.

58. Chidel MA, Suh JH, Reddy CA, Chao ST, Lundbeck MF, Barnett GH. Application of recursive partitioning analysis and evaluation of the use of whole brain radiation among patients treated with stereotactic radiosurgery for newly diagnosed brain metastases. Int J Radiat Oncol Biol Phys 2000;47(4):993-9.

59. Pirzkall A, Debus J, Lohr F, Fuss M, Rhein B, Engenhart-Cabillic R, Wannenmacher $M$. Radiosurgery alone or in combination with whole-brain radiotherapy for brain metastases. J Clin Oncol 1998;16(11):3563-9.

60. Sneed PK, Suh JH, Goetsch SJ, Sanghavi SN, Chappell R, Buatti JM, Regine WF, Weltman E, King VJ, Breneman JC, Sperduto PW, Mehta MP. A multi-institutional review of radiosurgery alone vs. radiosurgery with whole brain radiotherapy as the initial management of brain metastases. Int J Radiat Oncol Biol Phys 2002;53(3):519-26. 